\title{
FOREIGN DIRECT INVESTMENT IMPACT ON MARKET CONCENTRATION IN THE MANUFACTURING SECTOR OF BOSNIA AND HERZEGOVINA
}

\author{
UDC 339.727.22:339.1(497.6) \\ 67.01(497.6)
}

\section{Radovan Kastratović}

Institute for Business Research - MBA, Serbia

\begin{abstract}
There is no consensus regarding the effect of foreign direct investment on market concentration in the literature of foreign direct investment and the theory of industrial organization. The aim of the research is to empirically investigate this impact in the context of the manufacturing sector of Bosnia and Herzegovina. To achieve this aim we estimate the econometric model by applying ordinary least square method. The sample of 21 industries comprising the manufacturing sector of Bosnia and Herzegovina was used for model estimation. Cross-sectional sample data was obtained from the Central Bank of Bosnia and Herzegovina and the financial reports of 4924 companies registered in the aforementioned industries for the year 2016. The results suggest that the impact of foreign direct investment on market concentration can best be described with a convex function.
\end{abstract}

Key words: foreign direct investment, market concentration, competition

JEL Classification: F21, F23, L11

\section{INTRODUCTION}

Foreign direct investment may have different sorts of impact on the host economy: the increase in output, employment and export, the transfer of new technologies and knowledge and the growth of productivity. Another significant effect of foreign direct investment is the modification of market structure. The aim of the research is to examine the impact of foreign direct investment on the market structure of the manufacturing sector of Bosnia and Herzegovina.

Received November 14, 2017 / Revised December 29, 2017 / Revised March 19, 2018 / Accepted April 13, 2018

Corresponding author: Radovan Kastratović

Institute for Business Research - MBA, Belgrade Serbia

E-mail: radovan.kastratovic@institutmba.co.rs 
According to the data of The United Nations Conference on Trade and Development (UNCTAD), in 2016, Bosnia and Herzegovina recorded the inflows of foreign direct investment of 258.24 million USD, which constituted $1.75 \%$ of gross domestic product (UNCTAD, 2017). Such results could be characterized as modest, considering the levels of investment flows preceding the Global financial crisis. Future growth of foreign direct investment inflows can be expected with the further globalization, liberalization of the economy of Bosnia and Herzegovina, the acceleration of the reforms and European Union accession (Domazet, 2016). This brings up the question of the potential effects of the aforementioned growth, and this research aims to provide a partial answer.

The impact of foreign direct investment on market concentration is the question with an interesting theoretical aspect. There is still no consensus regarding this question in the theory of industrial organization. At least two conflicting hypotheses exist: the first - that foreign investments increase market concentration, and the second - that, to the contrary, they reduce it. There are theoretical viewpoints according to which the impact of foreign direct investment on market concentration levels can best be described with nonlinear functional forms, particularly in transition countries. The aforesaid hypotheses were tested in a vast number of empirical works in both developed and developing countries without conclusive results. For this reason, it is import to conduct further empirical research in order to improve the understanding of this problem, especially in the countries in which similar research has not previously been conducted. Such are all the countries in Southeastern Europe, including Bosnia and Herzegovina.

This research aims to provide the answer to the question of foreign direct investment impact on market concentration. We test the hypothesis that the impact of foreign direct investment on market concentration is statistically significant, and that it can best be described by a quadratic functional form. The sample includes 21 industries which constitute the manufacturing sector of Bosnia and Herzegovina. The cross-sectional data was obtained from the financial reports of 4924 companies in 2016. It was used to test the hypothesis by estimating a multiple econometric model, using the method of ordinary least squares. The results confirm the initial hypothesis that the impact of foreign direct investment on market concentration levels can be described by the convex functional form. It can be concluded that this functional form is suitable for describing the effect of foreign direct investment on market concentration in transition countries.

The paper is organized as follows. The first section reviews the related theoretical and empirical research. The second section outlays the applied econometric methodology, the construction of the variables used in the model and provides preliminary descriptive analysis of the sample used. In the following section the key empirical results of the research were described, upon which the relevant conclusions were drawn.

\section{FOREIGN DIRECT INVESTMENT AND MARKET CONCENTRATION}

Foreign direct investment can affect the host economy in different ways. One possible effect which is described in the theory of foreign direct investment is the impact on host country market structure (Markusen \& Venables, 1999). Market structure can be defined as the level and the type of rivalry which exists among the companies active in the related industries, offering similar products and employing similar marketing strategies (Dunning $\&$ Lundan, 2008, p. 531). The information regarding market structure can be obtained 
from market concentration. High levels of market concentration indicate an uneven distribution of market power, where one or few market subjects realize a dominant position compared to the other market subjects. The dominant position implies that the companies with the highest market share can act independently from their competitors, buyers and suppliers. Such a dominant position could be abused, which could in turn reflect on the dominant company influencing market prices and imposing unfavorable terms of trade to the other market subjects.

The dominant position of a company is not forbidden per se, but its abuse is. The abuse is problematic, as the monopolist is not under competitive pressure to improve the efficiency. In this situation, the prices are higher than in the case of higher competition, at the expense of the other competitors and the final consumers. The abuse of market power transfers the assets from the consumers to capital owners, which increases the inequality of the income distribution. The above-average profits realized from the abuse of dominant position by foreign companies can either be repatriated or retained and reinvested, which, as indicated by Newfarmer and Marsh (1981, p.73), can further strengthen their dominant position and increase the income distribution inequality.

The impact of foreign direct investment on market concentration is a controversial topic with two conflicting hypotheses (Forte, 2016, p. 241). The first hypothesis states that foreign direct investment reduces concentration on host country markets and spurs competition in the industries with entry barriers which are too high for local companies. The second hypothesis is that multinational companies increase market concentration levels by entering the markets of host country, reducing the intensity of the competition and raising entry barriers for the potential competitors.

In the short term, the effect of foreign direct investment on market concentration largely depends on the foreign company's mode of entry. One of the most common modes of entry in the recent decades is mergers and acquisitions. This mode does not impact market concentration levels in the short term, as the acquisitions of local companies change neither the total number of companies on the market nor their market shares. It could potentially increase competition when the acquisition target is a company with poor performances which would leave the market in the absence of the acquisition. In the case of greenfield investment, a foreign investor creates an entirely new company on the host market, which instantly increases the number of competitors and reduces market concentration. The impact of joint ventures on market concentration cannot be theoretically determined in advance, as it depends on the concrete arrangement among the partners.

In the long term, the effect of foreign direct investment on market concentration depends on the competitive strength and technological level of other companies active on the host country's markets. If the local companies manage to benefit from the potential positive spillover effects and the technology diffusion occurs, then the gradual reduction of the differences in technology and efficiency between local and foreign companies can be expected. This results in the increase of competition intensity manifested in the decrease of host market concentration. However, if the local companies are not on the sufficient level of technological development, the existing technological gap between local and foreign companies widens. As a result, the relative efficiency of foreign companies compared to the local ones improves, and, consequently, they perform better, effectively crowding out of the local companies from the market and increasing the market concentration in the long run.

The effects of foreign direct investment on host country market structure also depend on the impact of foreign companies on raising or lowering market entry barriers. The entry 
barriers can be raised when foreign companies apply superior technology, organization, management and marketing, realizing competitive advantage over the domestic companies. Additionally, foreign companies have a considerable financial power, allowing them to tolerate losses in the short term until they neutralize any potential advantage of the local companies, as well as to engage in themselves in price wars against local competitors (Blomström, 1986, p. 524). These companies also face lower supply risks as they tend to rely on better, cheaper and more secure inputs in production from their global supply chains, unlike local companies. Likewise, foreign companies are advantageous due the information accumulated by all the affiliates over a long period and a number of markets (Newfarmer \& Marsh, 1981, p. 49). The strength of these companies further allows them to lobby with the host country policymakers more successfully. The financial sector of a host country can also be more interested in financing foreign companies, which are perceived as less risky than local companies, due to their size and reputation (Kokko \& Thang, 2014, p. 57).

Multinational companies and local companies compete in production factors markets as well (Barrios et al., 2005, p. 1762). Particularly important is the ability to attract high quality workforce by foreign companies, due to the ability to offer higher salaries than their domestic counterparts. Besides, the superior working conditions in foreign companies might attract potential entrepreneurs, reducing the entrepreneurship development of the host country, and consequently lowering the number market entrants (Grossman, 1984). The previously described dynamics are likely to result in the increase of market concentration through crowding out of local competitors from the market and pressuring the remaining competitors to consolidate and merge as a response to the challenges brought by the presence of foreign affiliates.

Foreign direct investment can also reduce the entry barriers. If monopolistic structures already exist on the host market, the entry of foreign investors can spur the competition either directly or indirectly, through the creation of additional demand on the related host country markets and the spillover effects which could increase local companies' productivity.

There are factors with the opposing effects of foreign direct investment on market concentration. Thus, the theoretic models cannot precisely predict the eventual outcome. Caves (1971) was among the first to establish the theoretical problem of the effect of foreign direct investment on market concentration. In their seminal work investigating the determinants of market concentration, Caves and Porter (1980) single out economies of scale as the key determinant of market concentration, while predicting a negative effect of foreign direct investment. There is also a theoretical model in the literature predicting either a positive or negative effect of foreign direct investment on market concentration, depending on the position of the concrete market in the value chain (Markusen \& Venables, 1999), and the theoretical model describing the effect of foreign direct investment on market concentration with the convex function (Barrios et al., 2005).

As a result of contradicting theoretical expectations, it is necessary to isolate the net effect of foreign direct investment on market concentration in host countries, through empirical research. The search of the existing literature showed that there have been at least 16 empirical researches investigating this problem in the period from 1970 to 2017, which are discussed below. The aforementioned researches observed both developed and developing countries, obtaining different results and drawing different conclusions. The consensus regarding neither the direction of the foreign direct investment effect on market concentration nor the optimal methodological framework has yet been reached. 
The initial studies exploring the relationship between foreign direct investment and market concentration were conducted in developed countries. One of the first such pioneering works was performed by Rosenbluth (1970), who empirically found a weak, yet statistically significant correlation between the two variables. Following this research, Caves (1974) has also empirically demonstrated how multinational companies act as a driving force of the competition on the markets of The United States, Canada and Australia. Using the example of the Greek manufacturing sector, Bourlakis (1987) demonstrated that foreign direct investment increase market concentration. To the contrary, Driffield (2001) reached a contrasting conclusion by observing the manufacturing sector of the United Kingdom. Similarly, negative impact of foreign direct investment on market concentration was identified in the manufacturing sector of Portugal (Forte \& Sarmento, 2014). Finally, Barrios, Görg and Strobl (2005) found that the impact of foreign direct investment on market concentration can best be described by a quadratic function in the case of Irish manufacturing sector.

The existing empirical studies based on developing countries indicate a positive impact of foreign direct investment on market concentration. One of the earliest such studies was conducted by Lall (1979) who found a positive impact of foreign direct investment on market concentration in the case of Malaysian manufacturing sector. Similarly, Newfarmer and Marsh (1981) found a positive correlation between foreign direct investment and market concentration in the case of Brazilian electric industry. More generalizable results were obtained by Blomström (1986) and Willmore (1989) who studied the entire manufacturing industries of Brazil and Mexico respectively. Both authors identified a positive impact of foreign direct investment on market concentration. More recently, Singh, Joseph and Abraham (2011) and Adam and Khalifah (2012) reported similar findings by observing Indian and Malaysian manufacturing industries respectively. Lastly, Kokko and Thang (2014) studied the entire economy of Vietnam, determining a similar positive impact found in the previous studies in developing countries.

The empirical literature treating transition countries is limited. The only work observing a transition country in a manner similar to the previously discussed studies is the one by Amess and Roberts (2005). The authors report that in the case of Polish manufacturing sector foreign direct investment increases market concentration to a certain extent, after which its effect is reversed.

Additionally, Rutkowski (2006) analyzed 13 transition countries from Central and Eastern Europe finding a negative impact of foreign direct investment on market concentration. Orazalin and Dulambaeva (2013) report the same findings for the case of 26 transition countries of the Commonwealth of Independent States and Central and Eastern Europe. Both of these cross-country studies use the perception of local managers as the measurement of market concentration which is an imprecise and unreliable measurement.

It is not possible to draw an unambiguous conclusion regarding the impact of foreign direct investment on market concentration from the previous empirical work. The best solution for future research of the problem seems to be the observation of an individual country and groups of markets and case analysis.

The existing research of market concentration in Bosnia and Herzegovina predominantly focused on individual market concentration and competition analysis, such as the analysis of insurance industry (Tomaš, 2013) and the analysis of personal consumption market (Kasumović \& Meholjić Kalajdžić, 2013). So far, the effect of foreign direct investment on the market concentration of the markets of Bosnia and Herzegovina has not yet been investigated, which is the objective of this research. 


\section{METHODOLOGY}

The research design is based on secondary data. Drawing from the theory of industrial organization, the most extensively defined econometric model was specified, considering conventionally accepted practice of the related empirical work and the availability of data. By applying the deductive methodological approach, the model was gradually restricted by excluding the statistically insignificant variables. The reduced model was estimated by applying the appropriate econometric methods, using the second hierarchical level of industries of Statistical classification of economic activities in the European Community (NACE revision 2) which comprise the manufacturing sector as the unit of analysis. The most empirical research regarding the impact of foreign direct investment on market concentration is based on cross-sectional data analysis, which was also implemented in this research. The approach entails the estimation of a single regression equation for a specified moment in time on cross-sectional data regarding foreign direct investment and other variables potentially affecting market concentration. This allows the estimation of the effects of foreign direct investment on market concentration levels in the state of equilibrium. However, the process of reaching the equilibrium is dynamic, hence the occurring adjustments might somewhat blur the quantitative results. Panel data analysis could improve the results clarity and resolve the possible problems of endogeneity. However, is not applicable in this research due to the nature of the data under disposal.

Following the approach of Forte and Sarmento (2014), the model is specified in the most general form as:

$$
C=f(F D I, D)
$$

where $C$ represents market concentration, $F D I$ foreign direct investment and $D$ vector of other market concentration determinants. Next is the question of functional form in the equation (1). Linear functional form for all the determinants of market concentration is most commonly used in the literature, which was implemented in the research. Foreign direct investment variable is included in both linear and nonlinear functional form in the related research, depending on the characteristics of the country observed. Amess and Roberts (2005) propose the application of quadratic function for transition countries. Given the fact that Bosnia and Herzegovina is a transition country and the results of preliminary statistical analysis revealing the suitability of this approach, the foreign direct investment variable was modeled with a quadratic functional form.

Dependent variable in the research is market concentration $(C)$. The definition of relevant market is crucial for the operationalization of this variable. It consists of three components: product, spatial and temporal. The relevant product market in the research is defined as a second level of hierarchy (2-digit code) of Statistical classification of economic activities in the European Community. Such a definition of relevant product market is problematic as the level of aggregation is high, and it implicitly assumes that the observed companies operate only in the sectors of their corresponding statistical class. Therefore, the interpretation of market concentration should be made with caution. The estimated concentration on a market defined as described is merely an approximation, most likely higher than the actual level of market concentration. Regardless of the limitations, the presented definition of relevant market was implemented in the research, due to the availability of data regarding foreign direct investment. The relevant market was spatially determined as the territory of Bosnia and Herzegovina. It is plausible that there are 
companies in certain industries which are focused on more narrowly geographically defined markets. Nevertheless, given the high level of data aggregation, the relevant market determination as a territory of a country can be considered an adequate approximation.

The majority of previous research of foreign direct investment effects on market concentration employed discrete indicators of market concentration, that is, different ratios of concentration. Some of the exceptions include studies conducted by Amess and Roberts (2005) and Blomström (1986), which utilize Herfindahl-Hirschman index (HHI). The advantages of employing HHI index are multifold. Firstly, this indicator is cumulative and the information obtained from it is more precise. Secondly, this indicator is suitable for comparison of concentration in different industries, which precisely is the aim of the research. Finally, the indicator is used in antitrust procedures of numerous regulatory bodies, including inter alia the European Commission. For the outlined reasons, the research employs HHI index as the main measurement of market concentration. The index is determined for every industry following the approach of Hirschman (1964) as:

$$
\sum_{i=1}^{n_{j}} S_{i}^{2}=\sum_{i=1}^{n_{j}}\left(\frac{R_{i}}{R_{j}}\right)^{2}=\sum_{i=1}^{n_{j}}\left(\frac{R_{i}}{\sum_{i=1}^{n_{j}} R_{i}}\right)^{2}
$$

where $S_{i}^{2}$ represents market share of every individual company calculated as a ratio of total income of an individual company $\left(R_{i}\right)$ and the total income of all the companies in a given industry $\left(R_{j}\right), i=1, \ldots, n_{j}$ is the index of individual companies within the same industry, where $n_{j}$ is the total number of companies in $\mathrm{j}$-th industry, while $\mathrm{j}$ represents the index of two-digit codes of industries. The problem with the application of the equation (2) reflects in the fact that the total revenue of an individual company does not necessarily exclusively refer to one industry. However, the data from the analytical accounting for the companies of Bosnia and Herzegovina are not publicly available, which prevents the precise separation of revenues according to the originating industries. Moreover, the computation of HHI index based on the revenue data from publicly available financial reports implies that the analysis omits the gray economy which, according to some estimates, comprises $24.5 \%$ of gross domestic product of Bosnia and Herzegovina (Ernst and Young, 2016, p. 36). As a result, the computed market concentration indicators in the research represent conservative estimates, and the actual levels of market concentration are likely lower.

To verify the robustness of the results, the alternative, discrete, measurement of market concentration was also used in the research - concentration ratio for eight of the largest companies in each observed industry $(C R 8)$, measured by total revenue. This indicator was determined for sets of companies sorted in descending order by total revenue as a ratio of the revenue of individual company and the sum of revenues of all the companies in the given industry.

Foreign direct investment levels are the independent variable in the research. The paper follows the definition of foreign direct investment, provided by Organization of Economic Cooperation and Development (OECD), according to which they represent a lasting interest of the investors, a resident of one country, in the company which is a resident of another country, where the lasting interest is defined as direct or indirect ownership of over $10 \%$ of voting-rights equity (OECD, 2008). The definition is used because the same definition is adopted by the Central Bank of Bosnia and Herzegovina 
(Centralna banka Bosne $i$ Hercegovine) in the compilation of foreign investment statistics, which was the source of data in the analysis. The independent variable was calculated as a ratio of total stock of foreign direct investment at two-digit industry level in Bosnia and Herzegovina at the end of 2016 and the total value of liabilities of all companies in each of the two-digit industries, which is based on the approach first employed by Bourlakis (1987, pp. 723-724). On the basis of previous research and preliminary statistical analysis, it is expected that the effect of foreign direct investment on market concentration can be described with a U-shaped function. That means that initially, when the levels of foreign direct investment are low, additional foreign direct investment results in the reduction of concentration level, but on the higher levels of foreign direct investment, it leads to the increase of market concentration.

The theory of industrial organization predicts an array of determinants affecting market concentration. Some of the most common include: differentiation levels $(D I F)$, economies of scale, capital intensity $(K L)$ and market size $(\mathrm{R})$. To obtain more precise results of eventual direct isolated effect of foreign direct investment on market concentration, it is necessary to include the aforementioned variables in the model as control variables.

Differentiation levels $(D I F)$ measures the importance of product differentiation for different industries. The level of differentiation is approximated in the research as a ratio of sum of the accounting position Intangible assets from the balance sheet of all the companies from a given industry and the total value of assets of all the companies in the industry. As the higher differentiation level in an industry can be understood as an entry barrier for new potential competitors, a positive effect of the variable can be expected.

Economies of scale in the markets are often quantified with the minimal efficient scale of production of a facility in a given industry. Precise computation of this measurement requires the information regarding the physical production scale of individual companies, which is not available in Bosnia and Herzegovina. Therefore, fixed costs $(F C)$ are used as a substitute instead, calculated as a ratio of total fixed costs (sum of accounting positions Labor costs, Amortization costs and Provisions from the income statement) for all the companies of a given industry, and sum of total business expenses of all the companies in the industry. It is likely that in the industries with relatively high fixed costs fewer companies can survive. Thus, a positive effect of this variable on market concentration is expected.

Capital intensity $(K L)$ might also have an impact on market concentration. The research follows the approach of Adam and Khalifah (2012) and Forte and Sarmento (2014), where the capital intensity is measured as the ratio of total assets and total number of employees in a given industry. It is probable that the more capital intensive industries will contain a smaller number of companies compared to the other industries, hence the positive effect of this variable on market concentration can be expected.

Finally, market concentration may also be affected by market size $(R)$. The research measures market size as total revenues of all the companies competing on the relevant market. As larger markets allow more companies to operate, the negative effect of this variable on market concentration is anticipated.

The sample data consists of 21 two-digit manufacturing industries. The manufacturing sector consists of 24 such industries; three industries were, however, excluded from further analysis because the data regarding foreign investments in these industries was not available. Data regarding foreign direct investment stock were obtained from Panorama Nekto database of the Central Bank of Bosnia and Herzegovina. All the other data used in the research are obtained from the financial reports of 4924 companies 
registered in the manufacturing sector for the year 2016. The reports are publicly available on the web-sites of Financial Intelligence Agency (Finansijsko-informatička agencija) and Agency for Intermediary, IT and financial services (Agencija za posredničke, informatičke $i$ finansijske usluge). For the purpose of descriptive statistical analysis, all of the relevant markets were grouped in three categories, according to the level of market concentration measured by HHI index. For each category an average value of foreign direct investment $(F D I)$ on the markets was determined. The results are presented in Table 1.

Table 1 The average values of foreign direct investment levels on relevant markets with respect to the categories of market concentration

\begin{tabular}{lccc}
\hline HHI & Number of markets & Number of companies & Average FDI (\%) \\
\hline Less than 1000 & 13 & 4237 & 8.9 \\
1000-2000 & 5 & 541 & 19.81 \\
More than 2000 & 3 & 146 & 12.05 \\
\hline Total & 21 & 4924 & \\
\hline
\end{tabular}

Source: Author's calculations based on the data provided by the Central Bank of Bosnia and

Herzegovina, Financial Intelligence Agency and the Agency for Intermediary, IT and financial services

Table 1 shows that the majority of markets in the manufacturing sector of Bosnia and Herzegovina is within the zone of low concentration, as defined by the European Commission. Most of the companies in Bosnia and Herzegovina (86\%) compete on these markets. The lowest market concentration was recorded in the following industries: Manufacture of wood and of products of wood and cork, Manufacture of food products and Manufacture of rubber and plastic products (with the values of HHI index on the markets equaling approximately 71, 173 and 184, respectively). Three markets can be described as highly concentrated: Manufacture of coke and refined petroleum products, Manufacture of tobacco products and Manufacture of paper and paper products (with HHI index values of approximately 4752, 3778 and 2526, respectively). The highest level of foreign direct investment was reported in Tobacco products industry $(38.85 \%)$. It is noticeable that the markets with higher levels of foreign direct investment are also the markets characterized by a higher market concentration.

The descriptive statistics of the variables considered in the research is provided in Table 2.

Table 2 Descriptive statistics of the variables used in the empirical research

\begin{tabular}{lrrrr}
\hline Variable & Average & Minimum & Maximum & St. deviation \\
\hline HHI & 1144 & 73 & 4752 & 1217 \\
CR8 & 0.61 & 0.17 & 1.00 & 0.23 \\
FDI & 0.12 & -0.24 & 0.38 & 0.14 \\
DIF & 0.01 & 0.00 & 0.02 & 0.01 \\
FC & 0.24 & 0.11 & 0.44 & 0.09 \\
KL & 203763.10 & 33392.37 & 609395.20 & 145648.50 \\
R & 643341489 & 74010669 & 2721897968 & 633824175 \\
\hline
\end{tabular}

Source: Author's calculations based on the data provided by the Central Bank of Bosnia and Herzegovina, Financial Intelligence Agency and the Agency for Intermediary,

IT and financial services for the year 2016 
The econometric analysis is initiated by estimating the most general form of the model, including all the considered variables and the intercept. The model is presented in the equation (3) as:

$$
H H I=\beta_{0}+\beta_{1} F D I+\beta_{2} F D I^{2}+\beta_{3} D I F+\beta_{4} F C+\beta_{5} K L+\beta_{6} R+\varepsilon
$$

Market concentration was expressed in terms of quadratic function of foreign direct investment levels and the linear function of control variables. The impact of all the factors not explicitly included in the model is encompassed by error term $\varepsilon$. The model represented by the equation (3) was estimated using ordinary least squares method and performed by the software package Eviews 8. Statistically insignificant variables were iteratively excluded from the model, using the threshold of $10 \%$ significance. Variables differentiation level $(D I F)$, the share of fixed expenses in total expenses $(F C)$, market size $(R)$ and the intercept were thus eliminated. The reduced model maximizes Schwarz information criterion as well as the adjusted coefficient of determination and F-statistic. Significant reduction of the model was expected, because of a relatively small sample size, so the lack of statistical significance of the excluded variables does not necessarily rule out the possibility that these variables actually affect market concentration. However, in this concrete case it is capital intensity and foreign direct investment levels that predominantly determine market concentration, which can be expressed in terms of the equation (4):

$$
H H I=\beta_{1} F D I+\beta_{2} F D I^{2}+\beta_{3} K L+\varepsilon
$$

The model represented by the equation (4) was estimated using ordinary least squares. The residuals of the model are normally distributed, demonstrated by the value of JarqueBera statistics of 0.02. Autocorrelation of model residuals was tested using Durbin-Watson and Breusch-Godfrey LM test. Neither of the tests revealed the presence of autocorrelation. Breusch-Pagan and Glejser tests indicated no problems with heteroskedasticity. There is no statistically significant correlation between the regressors, meaning that multicollinearity is not present in the model, thus the estimates of the effects of the variables on market concentration are satisfactorily precise and separated. Finally, Ramsey regression equation specification error test indicated correct specification of the model represented by the equation (4) in terms of functional form, the choice of independent variables and the fulfillment of Gauss-Markov assumptions regarding the error term.

\section{RESULTS AND DISCUSSION}

The ordinary least squares estimation results of the equation (4) are presented in Table 3. The adjusted coefficient of determination shows that most of the variations of market concentration in the manufacturing sector of Bosnia and Herzegovina (76.29\%) were explained by the model. The regression is statistically significant at $1 \%$ level. 
Table 3 Regression Results

\begin{tabular}{lrlrr}
\hline $\begin{array}{l}\text { Dependent variable: HHI } \\
\text { Number of observation: } 21\end{array}$ & Coefficient & Std. error & t-statistic & p-value \\
\hline Variable & $0.00465^{*}$ & 0.000942 & 4.93 & 0.0001 \\
\hline KL & $-3449.47^{* *}$ & 1276.06 & -2.70 & 0.0146 \\
FDI & $16407.64^{* *}$ & 6352.39 & 2.58 & 0.0188 \\
FDI^2 & 0,786618 & $\overline{H H I}$ & 1144451 \\
$R^{2}$ & 0,762909 & S( $\overline{H H I})$ & & 1217083 \\
$\bar{R}^{2}$ & 592,6224 & Schwarz information crit. & 15,88777 \\
Std. error of reg. & 6321625 & DW-statistic & 1,969173 \\
SSR & 48,22432 & Probability (F) & 0,0000 \\
F-statistic & Source: Author's calculations &
\end{tabular}

Foreign direct investment $(F D I)$ statistically significantly affects market concentration measured by HHI index, after controlling for capital intensity of the industry. The effect can be described with quadratic functional form, as expected, and is significant at $5 \%$ level. This confirms the hypothesis that foreign direct investment affects market concentration negatively in the industries in which foreign direct investment levels are low, whereas after certain optimal point additional investments cause the increase in market concentration. Point estimate of the optimal point equals $10.51 \%$, and the confidence interval equals $(0.30 \%, 17.07 \%)$. The robustness of the obtained results was confirmed by replacing dependent variable with the ratio of concentration $(C R 8)$ and re-estimating the model. In this case the effect of foreign direct investment on market concentration was again statistically significant (this time at $10 \%$ level). The results are in line with the findings of Barrios et al. (2005) and Amess and Roberts (2005).

As anticipated, the control variable of capital intensity has a statistically significant and positive effect on market concentration at $1 \%$ level. The higher the capital requirements in an industry, the fewer companies can respond to such requirements and, in general, only few companies can maintain sufficiently large scale of production to be profitable.

The results suggest that there is an optimal point of foreign direct investment levels which minimizes market concentration. This is possibly due to the existence of monopolistic structures in the industries with low foreign direct investment levels. With the increase of foreign direct investment inflows, these structures disintegrate and the inefficient companies leave the market or restructure. The positions of the companies leaving the market are taken by the more efficient foreign companies. Their presence leads to positive spillover effects which improve the performances of other, local companies which eventually results in the intensified competition and is reflected by the reduced values of HHI index. However, the results reveal that such dynamic exists only to the extent where foreign companies do not become dominant market subjects. At that point dominant foreign companies seem to dominate the local counterparts by applying some or all of the factors such as: superior technology, possibilities of lobbying, greater financial strength and possibilities to acquire resources on the factors of production markets. The insufficiently developed local companies leave the market or consolidate in response to the described competitive pressures, which results in the progressive growth of HHI index. It should be taken into account that the increase of HHI index cannot be considered detrimental per se. It implies 
that few companies realize dominant market position, but it does not necessarily signify the abuse of it. Nevertheless, such situation, regardless of its effect on final product market prices limits the possibilities of small local competitors' development.

\section{CONCLUSION}

The research investigated the impact of foreign direct investment on market concentration in the manufacturing sector of Bosnia and Herzegovina. The ordinary least squares model of the impact of foreign direct investment on market concentration was estimated based on crosssectional financial data of 4924 companies from 21 markets for the year 2016.

The results reveal the existence of statistically significant effect of foreign direct investment on market concentration, robust to the choice of market concentration measurement, which can best be described with quadratic U-shaped functional form. In other words, when the levels of foreign direct investment are lower, their additional inflows lead to the reduction of market concentration, which is true up to a certain optimum. After this point, the additional inflows of foreign direct investment progressively increase market concentration.

These results confirm the findings of the related research in transition countries, particularly the one by Amess and Roberts (2005). It is, therefore, possible that there is certain regularity in transition countries regarding the effect of foreign direct investment on market structure in manufacturing sector. The inflows of foreign direct investment are simultaneously followed by both positive and negative effects affecting the market structure. On the markets with significant foreign companies' presence, the additional inflows of foreign direct investment results in the negative effects overpowering the positive ones, leading to the consolidation of market subjects and the increase of market concentration.

Such results might have important implications for the policy regarding the attraction and promotion of foreign direct investment and antitrust policy. The interest of transition countries in attracting foreign direct investment expecting their positive effects is evident from their efforts and provided incentives. However, the potential negative effects must also be taken into consideration. The results suggest that in the foreign investment promotion policies it is necessary to take into account the local companies' level of development and their ability to absorb the expected spillover effects. Excessive insistence on foreign investments in the markets where local companies are insufficiently developed to compete with foreign counterparts can limit their growth possibilities and even survival. Eventually, such dynamics might lead to the domination of foreign companies over the markets of Bosnia and Herzegovina. It is therefore worthwhile for antitrust policy to beware the possibilities of dominant position abuse by the largest foreign companies.

At the moment, however, the majority of the industries comprising the manufacturing sector of Bosnia and Herzegovina are within the zone of low concentration and the overall state of competition can be described as satisfactory. In the previous years, the country has made progress in antitrust regulation. Still, the room for improvement exists in the efficiency of the Competition Council and the harmonization of the Bosnian competition regulation with the regulation of the European Union. Finally, the industries with the highest foreign presence are also the most concentrated, which raises concerns regarding the possibilities of market power abuse by the dominant foreign companies, especially with the further foreign direct investment inflows. 
Further research regarding the effect of foreign direct investment on market concentration, should be based on larger sample, including time component and lower aggregation level of data in order to allow the application of panel data methodology. This would increase the precision of the estimates and help investigate the possible existence of the simultaneous effect between the two analyzed variables. Furthermore, future work should focus on the effect of market concentration on final consumers in order to provide better understanding of the problem as a whole. It should investigate whether the increased market concentration has an impact on profit margin and final product prices on respective markets.

\section{REFERENCES}

Adam, R. \& Khalifah, N.A. (2012). Foreign presence and market concentration in Malaysian manufacturing industries. Jurnal Ekonomi Malaysia, 46 (1), 119-132.

Agencija za posredničke, informatičke i finansijske usluge. Retrieved from: www.apif.net, Accessed on: 19 September 2017.

Amess, K. \& Roberts, B.M. (2005). The impact of foreign and state ownership on post-transition industrial concentration: the case of Polish manufacturing. Economic Change and Restructuring, 38, 211-225.

Barrios, S., Görg, H. \& Strobl, E. (2005). Foreign direct investment, competition and industrial development in the host country. European Economic Review, 49, 1761-1784.

Blomström, M. (1986). Multinationals and market structure in Mexico. World Development, 14 (4), 523-530.

Bourlakis, C.A. (1987). Multinational corporations and domestic market structure: The case of Greek manufacturing industries. Weltwirtschaftliches Archiv, 123, 719-733.

Caves, R.E. (1971). International Corporations: The Industrial Economics of Foreign Investment. Economica, 38 (149), 1-27.

Caves, R.E. (1974). Multinational Firms, Competition, and Productivity in Host-Country Markets. Economica, 41 (162), 176-193.

Caves, R.E. \& Porter, M.E. (1980). The Dynamics of Changing Seller Concentration. The Journal of Industrial Economics, 29 (1), 1-15.

Centralna banka Bosne i Hercegovine, Panorama Nekto, Retrieved from: statistics.cbbh.ba, Accessed on: 19 September 2017.

Domazet, A. (2016). Strane direktne investicije u Bosni i Hercegovini: od zabluda neoliberalizma do pokretača ekonomskog rasta [Foreign Direct Investment in Bosnia and Herzegovina: From the Delusions of Neoliberalism to Drivers of Economic Growth]. Posebna izdanja Akademije nauka i umjetnosti BiH, 27 (2), 126-145.

Dunning, J.H., \& Lundan, S. (2008). Multinational enterprises and the global economy. Cheltenham: Edward Elgar Publishing.

Driffield, N. (2001). Inward Investment and Host Country Market Structure: The Case of the U.K. Review of Industrial Organization, 18, 363-378

Ernst and Young. (2016). Reducing the Shadow Economy through Electronic Payments: Bosnia and Herzegovina. Warsaw: EYGM Limited.

Finansijsko-informatička agencija. Retrieved from: www.fia.ba, Accessed on: 20 September 2017.

Forte, R.P. (2016). Multinational firms and host country market structure: A review of empirical literature. The Journal of International Trade \& Economic Development, 25 (2), 240-265.

Forte, R. \& Sarmento, P. (2014). Does FDI increase market concentration? An evaluation of the Portuguese manufacturing industries. Acta Oeconomica, 64 (4), 463-480.

Grossman, G.M. (1984). International Trade, Foreign Investment, and the Formation of the Entrepreneurial Class. American Economic Review, 73 (4), 605-614.

Hirschman, A.O. (1964). The Paternity of an Index. The American Economic Review, 54 (5), 761.

Kasumović, M. \& Meholjić Kalajdžić, S. (2013). Struktura tržišta osobne potrošnje u Bosni i Hercegovini [The Structure of Personal Consumption Market in Bosnia and Herzegovina]. Ekonomski vjesnik, 26 (2), 410-426.

Kokko, A. \& Thang, T.T. (2014). Foreign Direct Investment and the Survival of Domestic Private Firms in Viet Nam. Asian Development Review, 31 (1), 53-91.

Lall, S. (1979). Multinationals and Market Structure in an Open Developing Economy: The Case of Malaysia. Review of World Economics 115 (2), 325-350 
Markusen, J.R. \& Venables, A.J. (1999). Foreign direct investment as a catalyst for industrial development. European Economic Review, 43, 335-356.

Newfarmer, R.S. \& Marsh, L.C. (1981). Foreign ownership, market structure and industrial performance: Brazil's electrical industry. Journal of Development Economics, 8, 47-75.

Orazalin, R. \& Dulambaeva, R. (2013). FDI Impact on Host Country's Market Concentration and Profitability. Actual Problems of Economics, 139, 428-438.

OECD. (2008). OECD Benchmark Definition of Foreign Direct Investment: Fourth Edition 2008. Washington, DC: OECD Publishing.

Rosenbluth, G. (1970). The Relation between Foreign Control and Concentration in Canadian Industry. The Canadian Journal of Economics, 3 (1), 14-38.

Rutkowski, A. (2006). Inward FDI, concentration, and profitability in the CEECs: Were the domestic firms crowded out or strengthened? Transnational Corporations, 15 (3), 105-140.

Singh, J., Joseph, K. \& Abraham, V. (2011). Inward Investment and Market Structure in an Open Developing Economy: A Case of India's Manufacturing Sector. Indian Journal of Economics 2 (6), 286-297

Tomaš, D. (2013). Lorencova kriva kao pokazatelj tržišne koncentracije u sektoru osiguranja Republike Srpske [Lorenz Curve as an Indicator of Market Concentration in the Insurance Sector of the Republic of Srpska]. Financing, 4 (2), 22-29.

UNCTADstat. Retrieved from: unctadstat.unctad.org, Accessed on: 21 September 2017.

Willmore, L. (1989). Determinants of industrial structure: A Brazilian case study. World Development, 17 (10), 1601-1617

\section{UTICAJ STRANIH DIREKTNIH INVESTICIJA NA KONCENTRACIJU TRŽIŠTA U SEKTORU PRERAĐIVAČKE INDUSTRIJE BOSNE I HERCEGOVINE}

U literaturi stranih direktnih investicija i teorije industrijske organizacije ne postoji jedinstven stav po pitanju uticaja stranih direktnih investicija na stepen tržišne koncentracije. Cilj ovog rada je empirijsko ispitivanje ovog uticaja u slučaju prerađivačke industrije Bosne i Hercegovine. $U$ tu svrhu ocenjen je ekonometrijski model metodom običnih najmanjih kvadrata. Pri tome je korišćen uzorak od 21 delatnosti sektora prerađivačke industrije Bosne i Hercegovine. Izvori korišćenih uporednih podataka su Centralna banka Bosne i Hercegovine i finansijski izveštaji 4.924 preduzeća iz tih delatnosti za 2016. godinu. Rezultati istraživanja ukazuju na to da se uticaj stranih direktnih investicija na stepen tržišne koncentracije najbolje može opisati konveksnom funkcijom.

Ključne reči: strane direktne investicije, koncentracija tržišta, konkurencija 